\title{
CONTINUED DECREASE OF ICE-FLOW VELOCITY AT LEWIS GLACIER, MOUNT KENYA, EAST AFRICA
}

\author{
By STEFAN HASTENRATH
}

(Department of Meteorology, University of Wisconsin-Madison, Madison, Wisconsin 53706, U.S.A.)

\begin{abstract}
Our earlier monitoring program on Lewis Glacier, Mount Kenya, indicated a slow-down of the ice flow to January 1982, while based on the numerical modeling of the ice dynamics a further drastic decrease of the ice flow was predicted from the 1978 to the 1985 datum. This paper presents velocity measurements over the years 1982-83, 1984, and 1985. Changes of ice-flow conditions from 1978 to the mid 1980s are characterized by a velocity decrease by nearly half; a decrease of the maximum mass flux by more than half; a flattening and up-glacier shift of the velocity and mass-flux maxima; an up-glacier displacement of the transition between prevailingly longitudinal crevasses in the lower glacier and transverse crevasses in the upper glacier; and a terminus retreat by about $50 \mathrm{~m}$. In consequence of the very weak ice flow remaining in Lewis Glacier, thinning and terminus retreat of the glacier are now primarily controlled by the in-situ net balance.
\end{abstract}

\section{INTRODUCTION}

Tropical glaciers are a particularly climate-sensitive component of the environment. The documentation of glacier variations on a global scale is in fact the objective of an international monitoring program (Müller, 1977; Haeberli, 1985). As these published records show, however, sustained and systematic glacier observations from tropical mountain regions are scarce. In this perspective, the ongoing field program on Mount Kenya (Hastenrath, 1984, p. 143-284) gains special importance. The program of mass-balance and ice-flow monitoring on Lewis Glacier, in particular, is motivated by the desire to further the understanding of climate-cryosphere relationships and climate variations.

The ice-flow velocity pattern in Lewis Glacier and its long-term variations have been the topic of a series of papers (Hastenrath and Kruss, 1979, 1982; Hastenrath, 1983; Kruss and Hastenrath, 1983). These works have borne out a monotonic and drastic slow-down of ice flow from the turn of the century to January 1982, demonstrably as a direct consequence of unfavorable climatic changes, the prevailingly negative net balance, and the concomitant thinning of the glacier (Hastenrath and Kruss, 1982; Hastenrath, 1984 , p. 170-95). Moreover, based on the numerical modeling of the ice dynamics and the net balance during the budget year March 1979-March 1980, the following changes were predicted from the 1978 to the 1985 datum (Hastenrath and Kruss, 1982): a reduction of the ice-flow velocity by nearly a half and of the maximum mass flux by more than half; an up-glacier displacement of maximum velocity, maximum mass flux, and of the transition zone between longitudinal crevasses in the lower glacier and transverse crevasses in the upper glacier; a flattening of the velocity and mass-flux maxima, and less well-defined contrasts in crevasse orientation; and a terminus retreat of the order of $50 \mathrm{~m}$. It was further anticipated that continued negative net balance and diminishing ice movement would lead to the terminus retreat becoming increasingly determined by the in-situ net balance rather than the mass economy and flow dynamics of the glacier as a whole. The trend of velocity decrease was verified by observations through January 1982 (Kruss and Hastenrath, 1983).

This paper reports the velocity measurements over the years 1982-83, 1984, and 1985, and places the 1985 flow conditions in context with the published prediction from 1978 velocity observations.

\section{OBSERVATIONS}

For velocity measurements on Lewis Glacier prior to 1978, refer to Hastenrath and Kruss $(1979,1982)$ and Hastenrath $(1984$, p. 176-95). Immediately pertinent to this paper are the observations from 1978 onward.

A network of stakes was installed on Lewis Glacier in January 1978 and then repeatedly surveyed by optical theodolite and electronic distance-measuring equipment (EDM). The following time intervals are of interest here: 1978 (25-29 January 1978 to 28 December 1978-5 January 1979); 1979 (28 December 1978-5 January 1979 to 26-27 December 1979); 1978-79 (25-29 January 1978 to $26-27$ December 1979); 1980-81 (26-27 December 1979 to 25-26 January 1982); 1982-83 (25-26 January 1982 to $21-23$ December 1983); 1984 (21-23 December 1983 to 5-6 January 1985); and 1985 (5-6 January 1985 to $1-2$ January 1986).

Airborne mapping of the ice-surface topography of Lewis Glacier at a scale of $1: 2500$ has been performed for February 1974, February 1978, March 1982, January 1985, and March 1986 (Caukwell and Hastenrath, 1977, 1982; Hastenrath and Caukwell, 1979, in press).

\section{ICE-FLOW PATTERN}

Our regular airborne mapping of Lewis Glacier spans an interval of 12 years, during which considerable changes of surface topography have taken place, which in turn imply alterations of the surface-flow pattern. Figures 1 and 2 , depicting approximate flow-line patterns constructed from the surface topography, illustrate such changes between the 1974 and 1986 epochs. However, the central longitudinal line used as reference in the present study as well as in our work over the past decade continues to be representative of the overall flow conditions.

The distribution of ice-flow velocity for the three intervals 1982-83, 1984, and 1985 is mapped in Figures $3-5$. The spatial distribution of velocity vectors broadly agrees between the three time intervals, and also appears to be consistent with the surface stream-line patterns deduced from surface topography (Figs 1 and 2). An important difference between the three time intervals is the gradual slow-down of ice flow. While evident, this is not conspicuous on Figures 3-5.

From the maps (Figs 3-5), velocity along the longitudinal axis of the glacier (Figs 1-5) was also evaluated, in a way consistent with our previous work (Hastenrath and Kruss, 1982; Kruss and Hastenrath, 1983). Velocity values at stations on the central line were plotted against downglacier distances; where the location of survey targets is not close to the central line, values were derived allowing for the systematic increase of velocity from the boundaries towards the middle of the glacier. The raw velocity values thus obtained were also filtered using averaging over $100 \mathrm{~m}$ intervals, so as to remove the high-frequency spatial variations. The results are plotted in Figure 6.

An earlier paper (Hastenrath and Kruss, 1982, fig. 2) 


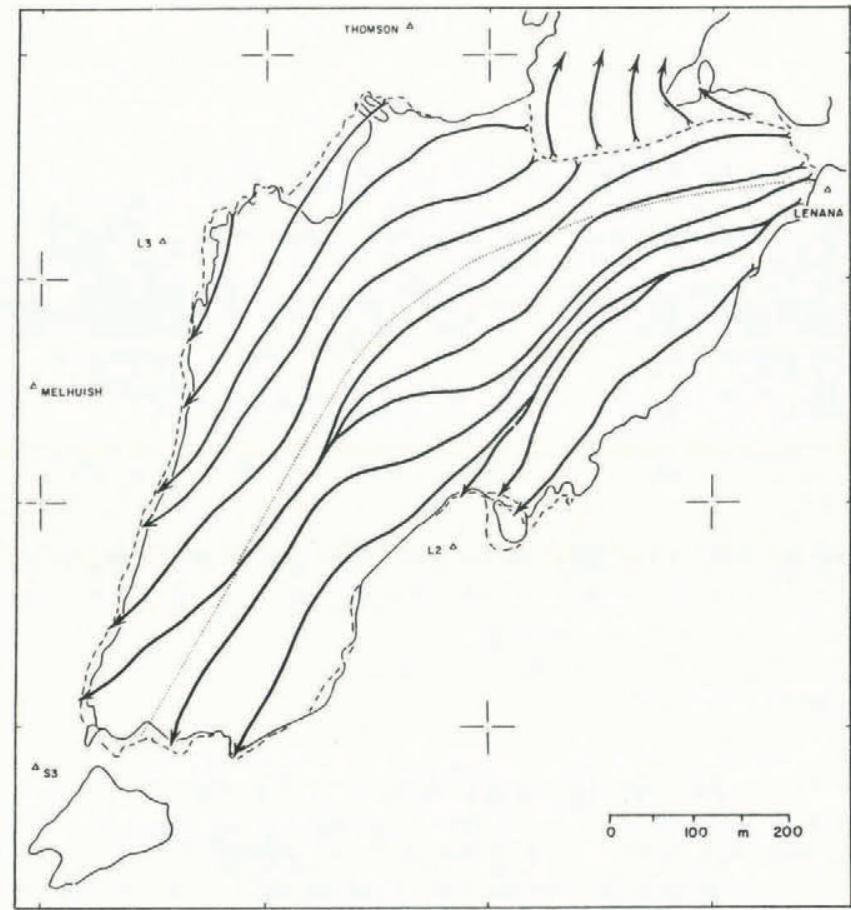

Fig. 1. Approximate flow-line pattern constructed from surface topography in February 1974. Dotted line represents a central longitudinal line, and broken and solid lines indicate the 1974 ice extents, respectively.

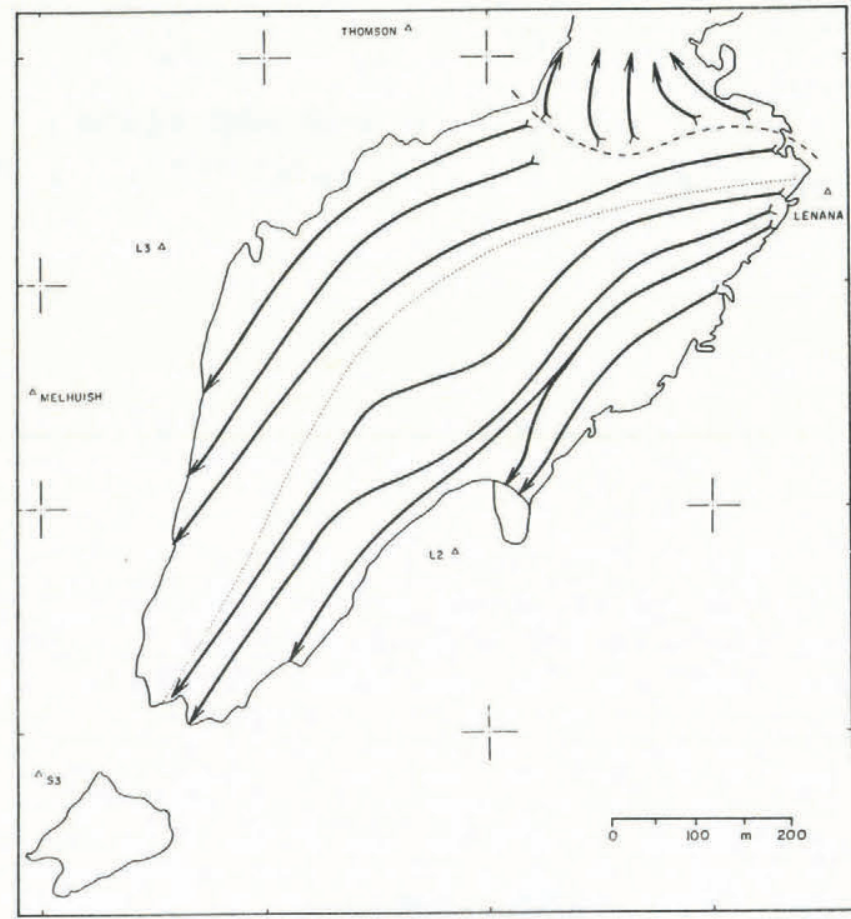

Fig. 2. Approximate flow-line pattern constructed from surface topography in February 1986. Dotted line represents a central longitudinal line.

presented the changes of the longitudinal velocity profile of Lewis Glacier from the turn of the century to 1978. The present Figure 6 extends this historical documentation to the mid 1980s. The most prominent changes in the velocity profile along the central longitudinal line from the turn of the century to 1978 are (i) a drastic overall slow-down, (ii) a displacement of the velocity maximum up-glacier, and (iii) a flattening of the velocity maximum. Figure 6 bears out the further accentuation of these features of development into the mid 1980s.

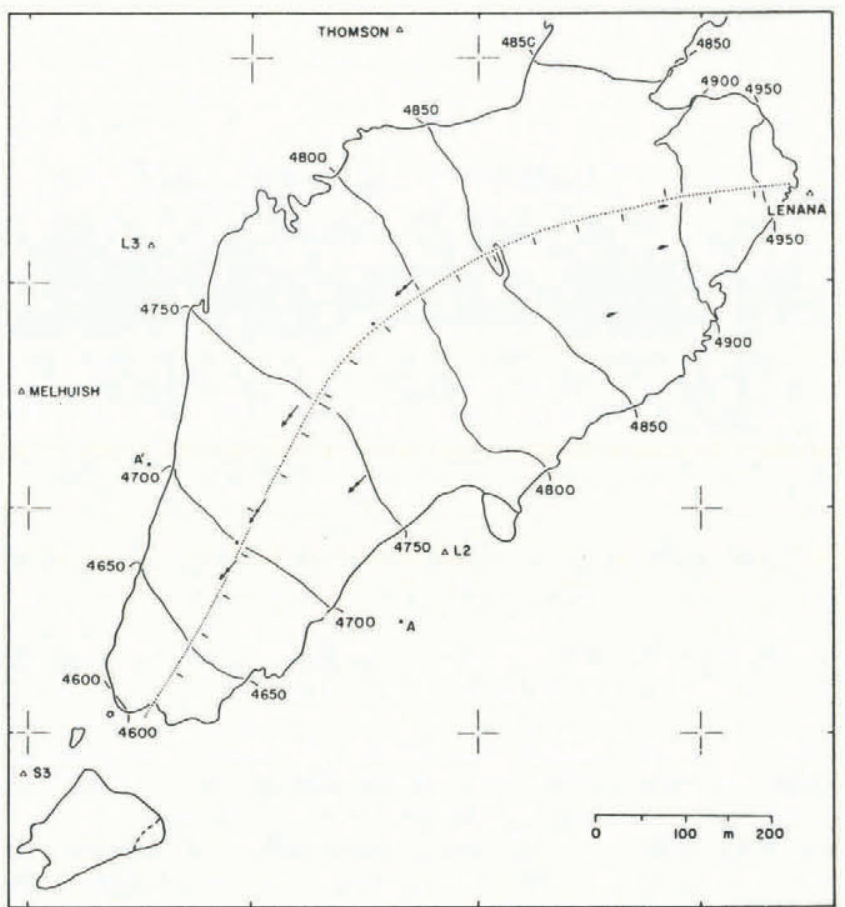

Fig. 3. Surface ice-flow pattern 1982-83 (25-26 January 1982 to 21-23 December 1983). Arrows indicate the direction and magnitude of horizontal velocity. Velocity scale in $m a^{-1}$ is ten times the horizontal map scale (i.e. a velocity of $10 \mathrm{~m} \mathrm{a}^{-1}$ would be represented as a $100 \mathrm{~m}$ arrow). The dotted line defines a central longitudinal line (see Figs 1-6) with tick marks at $50 \mathrm{~m}$ intervals indicating longitudinal distance from the highest point of glacier.

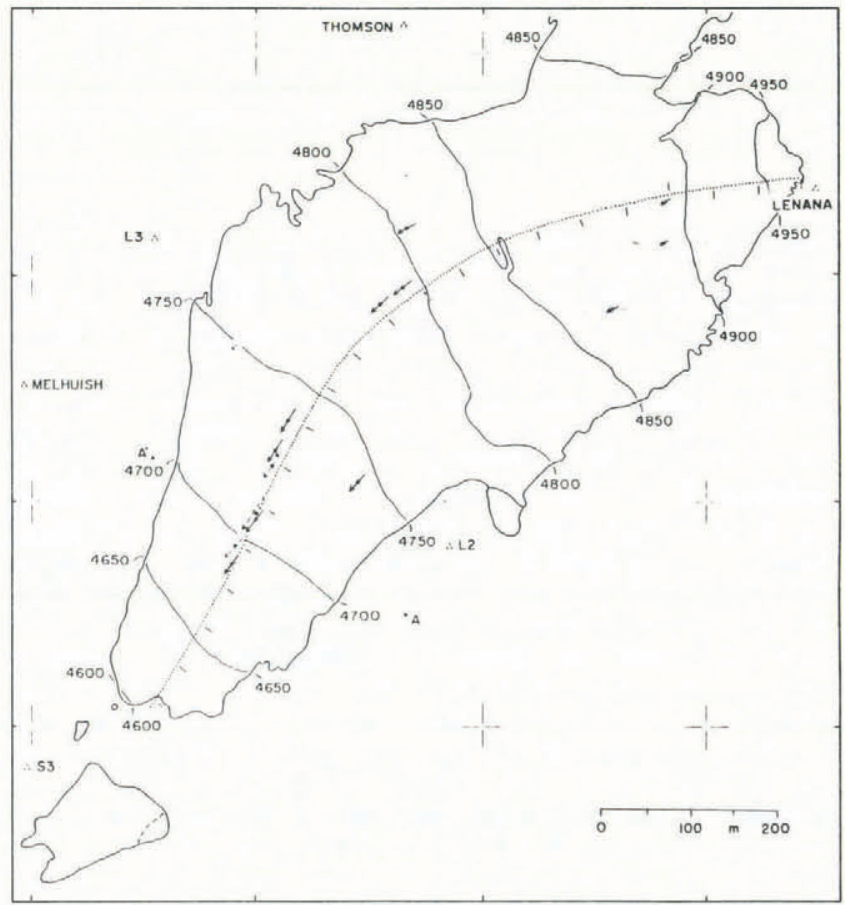

Fig. 4. Surface ice-flow pattern 1984 (21-23 December 1983 to 5-6 January 1985), solid arrows, and 1982-84 (25-26 January 1982 to 5-6 January 1985) broken line arrows. Other symbols and scale as for Figures 3-5. 


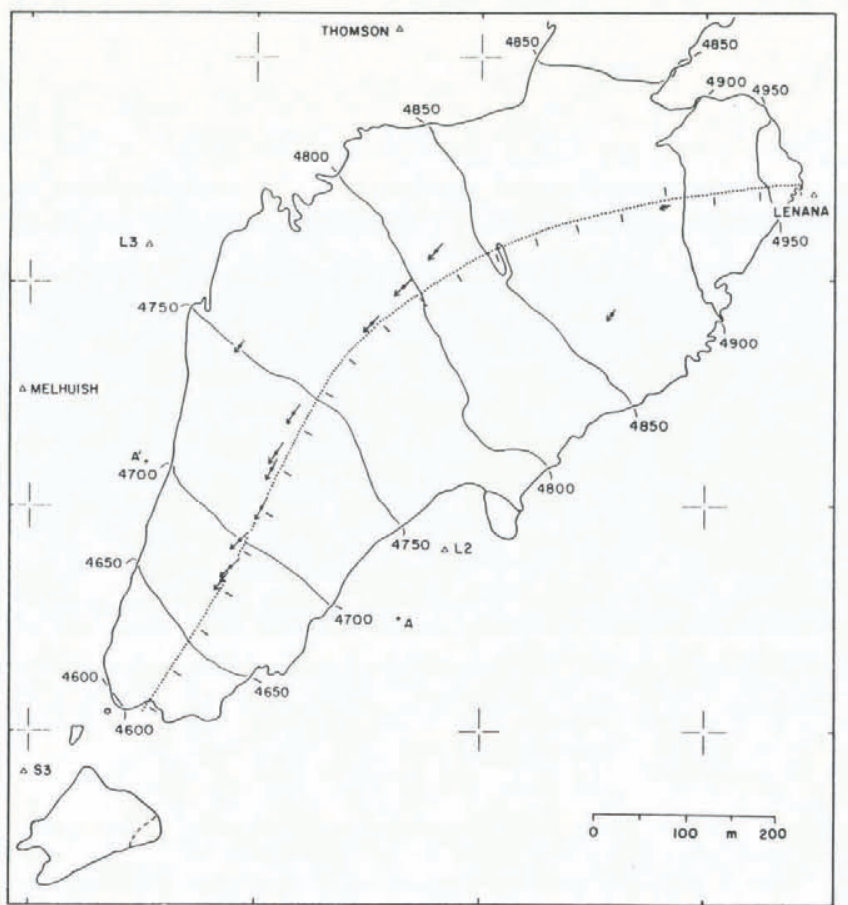

Fig. 5. Surface ice-flow pattern 1985 (5-6 January 1985 to 1-2 January 1986). Symbols and scale as for Figures 3-5.

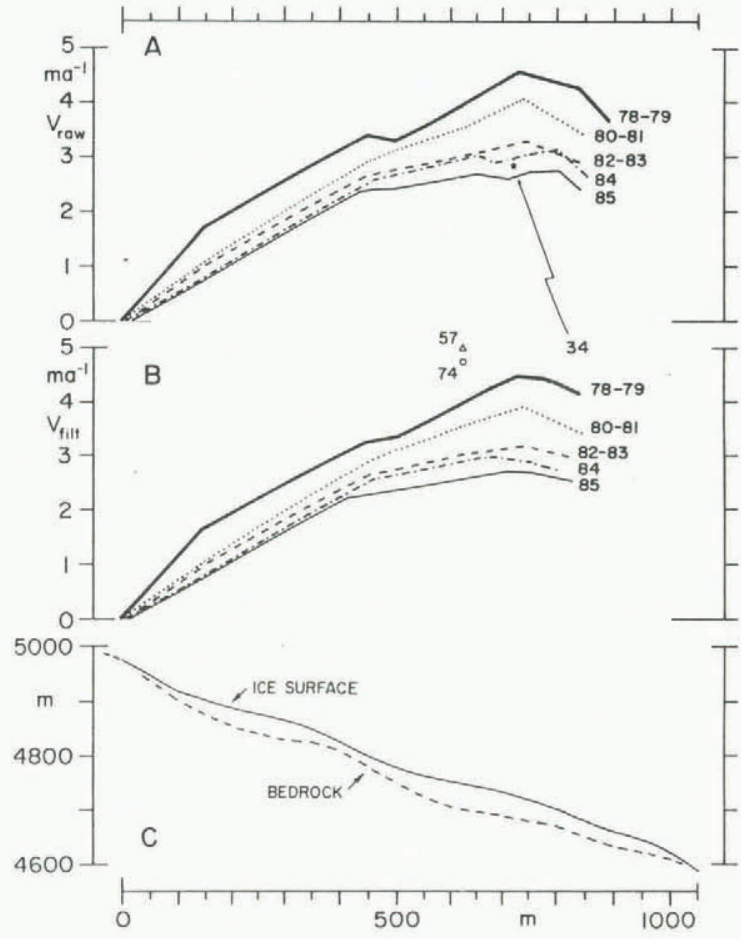

Fig. 6. Secular variation of horizontal surface velocity $\left(m a^{-1}\right)$ along central longitudinal line (see Figs 1-6). "Raw" observations are averaged over $100 \mathrm{~m}$ intervals to yield the "filtered" values. Time intervals given are as follows: 1978-79 (25-29 January 1978 to 26-27 December 1979) heavy solid line; 1980-81 (26-27 December 1979 to 25-26 January 1982) dotted; 1982-83 (25-26 January 1982 to 21-23 December 1983) broken; $1984 \quad(21-23$ December 1983 to 5-6 January 1985) dash-dotted; 1985 (5-6 January 1985 to 1-2 January 1986) thin solid line.

\section{COMPARISON WITH FORECAST}

The changes in the ice-flow characteristics of Lewis Glacier from 1978 to the mid 1980s will now be compared with the published predictions. These were based on the net balance during the budget year 1979 (March 1979-March 1980) of $-180 \mathrm{~cm}$ liquid water equivalent. The net balance values for the six subsequent budget years to March 1986 are $-120,-37,-72,-90,-95$, and $-68 \mathrm{~cm}$. The net balance for the 1978 budget year is $-10 \mathrm{~cm}$. Thus, the negative net balance for the average of the seven budget years 1979 through 1985 is rather less extreme than for the budget year 1979, namely $-95 \mathrm{~cm}$, or about half the 1979 value. Predicted and observed changes are in the following compared for the various ice-flow characteristics.

Velocity

Figure 6 illustrates the progressive velocity decrease from 1978 to the mid 1980 s. Note that the glacier mean value for 1978 is only $1 \%$ larger than that of 1978-79 depicted in Figure 6 (Hastenrath and Kruss, 1982; Kruss and Hastenrath, 1983). Table I gives values obtained by averaging over the entire longitudinal profile, as shown in

TABLE I. LONGITUDINAL MEAN FILTERED VELOCITY AND MAXIMUM MASS FLUX DURING 1978-85

\section{Velocity \\ $\mathrm{cm} \mathrm{a}^{-1}$}

$\begin{array}{ll}1978 & 291 \\ 1978-79 & 290 \\ 1980-81 & 244 \\ 1982-83 & 203 \\ 1984 & 196 \\ 1985 & 183\end{array}$

\section{Mass flux}

$10^{3} \mathrm{~m}^{3} \mathrm{a}^{-1}$ liquid water equivalent

$$
\begin{aligned}
& 32 \\
& 29 \\
& 24 \\
& 18 \\
& 17 \\
& 15
\end{aligned}
$$

Figure 6. The total velocity decrease from the 1978 to the 1985 epoch amounts to $37 \%$. This is consistent with the predicted decrease to about a half, inasmuch as the flow forecast was made on the premise of net balance conditions similar to 1979, while the negative net balance in the average over the 7 years $1979-85$ was only half as extreme as for the budget year 1979 .

Figure 6 demonstrates the progressive flattening and up-glacier displacement of the velocity maximum in the course of 1978-85, in accordance with the prediction, the up-glacier shift of the velocity maximum over the entire interval being of the order of $5 \mathrm{~m}$.

\section{Mass flux}

Concomitant with the progressive velocity decrease is a drastic reduction in the mass flux. Based on the velocity measurements and the cross-section shape of the glacier bed (Bhatt and others, 1980; Hastenrath, 1984, p. 162-64), the maximum mass flux in 1985 was estimated at $15 \times 10^{3} \mathrm{~m}^{3} \mathrm{a}^{-1}$, with a location at about $600 \mathrm{~m}$ downglacier distance measured from the highest point of the glacier. These values should be compared with the 1978 conditions, characterized by a maximum mass flux of $32 \times$ $10^{3} \mathrm{~m}^{3} \mathrm{a}^{-1}$ at $620 \mathrm{~m}$ down-glacier distance (see Fig. 6). Thus, from 1978 to the mid 1980s, the maximum mass flux decreased by about $53 \%$. The mass-flux maximum has also flattened, so that its shift up the glacier is not well defined.

\section{Crevasse pattern}

The relation between ice flow and crevasse patterns on Lewis Glacier has been discussed in an earlier paper (Hastenrath and Kruss, 1979). The velocity maximum marks the transition from expanding to compressive flow, and would thus be related to the prevalence of transverse crevasses in the upper glacier and of longitudinal crevasse orientation in the lower glacier. The shift in the velocity maximum of the glacier upward, as described above, would thus be conducive to an upward displacement of the transition between differing crevasse orientations in the upper glacier versus the lower glacier. As shown by Figure 
6, however, the velocity maximum had become very flat by 1985, thus mitigating the contrast between expanding and compressive flow. However, comparison of the 1982 and 1986 crevasse patterns (Hastenrath and Caukwell, in press) indeed indicates a weak tendency for this transition zone to shift up-glacier.

\section{Terminus retreat}

Our airborne mapping (Hastenrath and Caukwell, 1979 in press; Caukwell and Hastenrath, 1982) pinpoints the terminus elevation in February 1978, March 1982, January 1985, and March 1986, at 4588, 4598, 4601 and $4604 \mathrm{~m}$, respectively. Correspondingly, the terminus retreated from the 1978 position by horizontal distances of 42, 55, and $60 \mathrm{~m}$. The $60 \mathrm{~m}$ value for the time span from February 1978 to March 1986 agrees well with the retreat of about $50 \mathrm{~m}$ predicted for the interval $1978-85$.

\section{Net balance and surface lowering}

In an earlier analysis for the budget years 1978-82 (Hastenrath, 1983), it was found that in the lower glacier the observed surface lowering was less than the in-situ negative net balance, whereas in the upper glacier the topography decrease was larger than accounted for by the local net balance; the discrepancies resulting from the mass redistribution related to the ice-flow dynamics. As mentioned at the beginning of this paper, we conjectured in another paper (Hastenrath and Kruss, 1982) that continued negative net balance and reduction in ice flow would, by the mid 1980s, enhance the relative importance of the in-situ net balance for the lowering of the ice surface, so that the terminus retreat would become increasingly controlled by the in-situ net-balance conditions.

In our ongoing field program on Lewis Glacier, the ice-mass economy is assessed independently by the "glaciological" (stake network) and "geodetic" (repeated mapping of surface topography) methods (Hoinkes, 1970). Results from the two approaches have been compared previously for the time span 1978-82 (Hastenrath, 1983, 1984, p. 178-91). An analogous evaluation from the abovementioned two independent methods has now become possible for the 1982-86 interval, and results will be detailed elsewhere in due course. Implications relevant for the present purposes are as follows. In 1982-86, as in 1978-82, the negative net balance in the lower glacier was larger than the observed surface lowering. However, these discrepancies were smaller for $1982-86$ than in $1978-82$. This means that in the more recent time interval the observed thinning of the ice and, in fact, the terminus retreat were more strongly controlled by the in-situ net balance.

\section{CONCLUSIONS}

Continuing the history of ice-flow variations in Lewis Glacier since the turn of the century, our field program has included the systematic monitoring of ice velocity over the eight consecutive years since 1978. Based on the comprehensive exploration of bedrock and surface morphology, mass economy, kinematics, and the numerical modeling of the flow dynamics, predictions were made over a 7 year interval to the mid 1980s. These included statements on the anticipated overall velocity decrease, the location and shape of the maxima of velocity and mass flux, the alteration of the crevasse pattern, and the terminus retreat. The change in ice-flow conditions to the mid 1980s, as documented in this paper, are consistent with the evolution we anticipated. Note that these forecasts of glacier changes were made on the premise of net-balance conditions similar to the late 1970s. This was a prediction of glacier response, not a climate prediction. In fact, the negative net balance in the average over the 7 year forecast interval was less extreme than for the 1979 budget year used as reference.

In consequence of the very weak ice flow remaining in Lewis Glacier in the mid 1980s, the problem of glacier thinning and terminus retreat is now considerably simplified, in that these changes are now overwhelmingly controlled by the in-situ net balance. This state of affairs opens the prospect of estimating future changes in ice thickness, areal extent, and terminus, under the assumption that net-balance conditions will continue to be similar to those measured during the past 8 years. On these grounds, it is intended to make a prediction of the fate of Lewis Glacier to the end of the millenium.

In closing, I would like to recall that systematic observations of tropical glaciers are an important contribution to global climate and environment monitoring. While quantitative assessments of terminus variations should be made on a larger number of appropriately selected ice bodies, a comprehensive monitoring of mass economy, kinematics, and long-term area and volume changes, is desired at least for a few type glaciers in the tropics. Although these objectives could be accomplished with relatively modest material support at the international level, the regularly published records (Müller, 1977; Haeberli, 1985) regrettably show that collectively we are falling short of even these limited goals. Against this back-drop, the maintenance of the Lewis Glacier field program and the regular publication of results, as continued in this paper, become a considerable commitment.

\section{ACKNOWLEDGEMENTS}

This study was supported by U.S. National Science Foundation grant EAR83-17722 and National Geographic Society grant $2769-84$. P. Kruss participated in the 1981-82 field work, and N. Bhatt, R.A. Caukwell, and W. Hime, in the subsequent expeditions. The research was authorized by the Office of the President, Republic of Kenya.

\section{REFERENCES}

Bhatt, N., and others. 1980. Ice thickness determination at Lewis Glacier, Mount Kenya: seismology, gravimetry, dynamics, by N. Bhatt, S. Hastenrath, and P. Kruss. Zeitschrift für Gletscherkunde und Glazialgeologie, Bd. 16, Ht. 2, p. 213-28.

Caukwell, R.A., and Hastenrath, S. 1977. A new map of Lewis Glacier, Mount Kenya. Erdkunde, Bd. 31, Ht. 2, p. 85-87.

Caukwell, R.A., and Hastenrath, S. 1982. Variations of Lewis Glacier, Mount Kenya, 1978-82. Erdkunde, Bd. 36, Ht. 4, p. 293-303.

Haeberli, W. 1985. Fluctuations of glaciers 1975-80. (Vol. 4.) Paris, IAHS/UNESCO.

Hastenrath, S. 1983. Net balance, surface lowering, and ice flow pattern in the interior of Lewis Glacier, Mount Kenya, Kenya. Journal of Glaciology, Vol. 29, No. 103, p. 392-402.

Hastenrath, S. 1984. The glaciers of equatorial East Africa. Dordrecht, etc., D. Reidel publishing Co.

Hastenrath, S., and Caukwell, R.A. 1979. Variations of Lewis Glacier, Mount Kenya, 1974-78. Erdkunde, Bd. 33, Ht. 4, p. 292-97.

Hastenrath, S., and Caukwell, R.A. In press. Variations of Lewis Glacier, Mount Kenya, 1982-86. Erdkunde.

Hastenrath, S., and Kruss, P. 1979. Dynamics of crevasse pattern at Lewis Glacier, Mount Kenya. Zeitschrift für Gletscherkunde und Glazialgeologie, Bd. 15, Ht. 2, p. 201-07.

Hastenrath, S., and Kruss, P. 1982. On the secular variation of ice flow velocity at Lewis Glacier, Mount Kenya, Kenya. Journal of Glaciology, Vol. 28, No. 99, p. 333-39.

Hoinkes, H. 1970. Methoden und Möglichkeiten von Massenhaushaltsstudien auf Gletschern. Ergebnisse der Messreihe Hintereisferner (Ötztaler Alpen) 1953-1968. Zeitschrift für Gletscherkunde und Glazialgeologie, Bd. 6, p. 37-90.

Kruss, P., and Hastenrath, S. 1983. Variation of ice velocity at Lewis Glacier, Mount Kenya, Kenya: verification midway into a forecast. Journal of Glaciology, Vol, 29, No, 101, p. 48-54.

Müller, F. 1977. Fluctuations of glaciers 1970-1975. (Vol. 3.) Paris, IAHS/UNESCO. 